\title{
KUALITAS MEDIA CARD DANCE UNTUK PEMBELAJARAN SENI TARI DI LEMBAGA PENDIDIKAN
}

\author{
Emy Yunita Rahma Pratiwi ${ }^{1}$, Ratih Asmarani ${ }^{2}$ \\ Universitas Hasyim Asy'ari Tebuireng Jombang \\ Emyyunita88@gmail.com ${ }^{1}$, Ratihasmarani004@gmail.com ${ }^{2}$
}

\begin{abstract}
Abstrak
Tujuan pembelajaran seni tari carddancebagi pelajar adalah untuk mengekpresikan kembali pengalaman mereka yang lalu secara kreatif, memupuk dan mengembangkan daya ciptanya dan diekpresikan dalam bentuk seni karya tarian kreatif. Penelitian ini bertujuan untuk mengetahui kualitas media card dance. Media pembelajaran seni tari yang digunakan dalam hal ini adalah "Card Dance", yaitu sebuah kartu yang di dalamnya terdapat gambar tari yang ada di Indonesia.Penelitian ini adalahmenggunakan model pengembangan 4-D (Four D Models) dari Thiagarajandanjenis penelitian ini deskriptif kualitatifdengan kajian laporan hasil penelitian.Hasil data dari tim validator akan dianalisis secara deskriptif kuantitatif.Penelitian ini diharapkan memberikan manfaat pada pengembangan media card dance untuk pembelajaran seni tari dalam lembaga Pendidikan. Berdasarkan hasil kualitas media card dance untuk pembelajaranseni tari di lembaga pendidikan. Ditinjau dari berbagai aspek kualitas materi dan mediamenunjukkan total skor perolehan sebesar 109 dari total skor maksimal 148. Setelah dianalisis dan dipersentasekan, nilai tersebut mendapatkan hasil sebesar $74,5 \%$. Secara keseluruhan media card dance memenuhi syarat sebagai media yang berkualitas dengan kualittas baik dan layak digunakan untuk menunjang pembelajaran.
\end{abstract}

Kata Kunci: Kualitas Media Pembelajaran, Seni Tari, Card Dance, Lembaga Pendidikan

\begin{abstract}
The learning goal of card dance art for students is to re-express their past experience creatively, foster and develop creativitythat is expressed in the form of creative dance artwork. This study aims to determine the quality of card dance instructional media. The instructional media of dance art used is "Card Dance", which is a card with some pictures of Indonesian dance.This research used 4-D development model (Four D Models) from Thiagarajan and the research design is qualitative descriptive with discussion of the researchresult. The data collection results from the team validator will be analyzed descriptively and quantitatively. This research aims to provide benefits to the improvement of card dance media for learning dance art in educational institution.Based on the result of the card dance mediaquality to teach dance art at educational institution, and analyzed from several aspects of the quality of material and media, it shows the total score of 109 out of a maximum score of 148. After being analyzed and presented, the results obtained a result of $74.5 \%$. Overall, the instructional media of card dance can be defined as a good quality instructional media and deserve to be used to support learning.
\end{abstract}

Keywords: Quality of Instructional Media, Dance Art, CardDance, Educational Institution 


\section{PENDAHULUAN}

Pelajaran Seni Budaya diberikan dengan tujuan untuk memberikan pengalaman estetik pada siswa dalam bentuk kegiatan berekpresi, berkreasi dan berprestasi. Peran ini tidak dapat diberikan oleh mata pelajaran lain, hasil dari pembelajaran Siswa dibentuk agar mampu mengembangkan bakat dan kreativitasnya sesuai dengan pilihan dengan potensi diri yang dimiliki para siswa.

Tujuan pembelajaran seni tari bagi pelajar adalah untuk mengekpresikan kembali pengalaman mereka yang lalu secara kreatif, memupuk dan mengembangkan daya ciptanya dan diekpresikan dalam bentuk seni karya tarian kreatif.Tari kreatif menurut Gilbert (Desfina, 2002:3) mengatakan menggabungkan penguasaan pergerakan melalui seni ekpresi.Ia juga mengatakan pembelajaran seni tarian sekolah dapat mengembangkan cognitive autcomes, afective autcome, physical autcomes, social autcome.

Media pembelajaran seni tari yang digunakan dalam hal ini adalah "Card Dance", yaitu sebuah kartu yang di dalamnya terdapat gambar tari yang ada di Indonesia. Media ini berhasil diaplikasikan di kelas Seni Sabuk Janur di Padepokan Reyog Ponorogo, Berangkat dari keberhasilan tersebut, peneliti ingin membahas lebih lanjut tentang kualitas media Card Dancedalam pembelajaran seni tari di Lembaga Pendidikan di Indonesia, salah satu lembaga pendidikan di Indonesia adalah mahasiswa prodi PGSD Universitas Hasyim Asy'ari Tebuireng Jombang semester 5 sertaberdasarkan kajian literature yang ada.

Penggunaan media pembelajaran card dance ini sangat diperlukan dalam proses pembelajaran seni tari. Meskipun demikian, kualitas media pembelajaran yang dikembangkan tersebut tentunya menjadi hal utama yang harus tetap terjaga. Oleh karena masih diragukan terhadap media yang telah dikembangkan, maka perlu dilakukan pengujian kualitas terlebih dahulu. 


\section{METODE PENELITIAN}

Penelitian ini merupakan penelitian pengembangan $(R \& D)$ karena berusaha mengembangkan media pembelajaran seni tari. Selanjutnya hasil pengembangan ini akan diujicobakan dalam pembelajaran mata kuliah pendidikan seni tari dan drama pada prodi PGSD Fakultas Ilmu Pendidikan Universitas Hasyim Asy'ari pada semester 5, dan hasilnya akan dianalisis dengan dua cara. Hasil data dari observasi dan wawancara dianalisis secara deskriptif kualitatif dan hasil data dari tim validator akan dianalisis secara deskriptif kuantitatif. Objek penelitian ini adalah mahasiswa prodi PGSD semester 5 yang menempuh mata kuliah "pendidikan seni tari dan drama" yang berjumlah 40 orang. Metode pengumpulan data yang digunakan untuk memperoleh data yang dibutuhkan adalah metode observasi, wawancara, dan dokumentasi. Model pengembangan pada penelitian ini adalah mengacu pada Four-D Model yang dikemukakan oleh Thiagarajan, (1974) yang terdiri atas empat tahapan: 1) pendefinisasian (define), 2) perancangan (Design), 3) pengembangan (develope), dan 4) penyebaran (dissemination). Dalam penelitian ini tahap desiminasi tidak dimasukkan dalam tahapan penelitian media pembelajaran yang direncanakan. karena terbatasnya waktu, maka pelaksanaan langkah model tersebut hanya dibatasi sampai pada uji coba produk.

\section{HASIL DAN PEMBAHASAN}

Pembelajaran seni merupakan pembelajaran apresiasi tentang indah dan keindahan serta pemahaman terhadap karya orang lain. Melalui apresiasi seni orang akan menghargai karya orang lain. Jadi proses pembelajaran seni sebagai pendidikan rasa mempunyai korelasi positif dengan pendidikan toleransi dari sebagai pemindahan kecakapan (transfer of lerning) merasakan dan menghargai orang lain. Dalam pembelajaran tari tidak dimaksudkan siswa terampil menari untuk keperluan pentas. Akan tetapi fokus materi adalah proses kreatif siswa. 
Proses ini berguna untuk membantu pertumbuhan dan perkembangan kognitif, afektif dan psikomotorik siswa.

Pembelajaran seni melalui media Card Dance merupakan inovasi pengembangan media pembelajaran, Card Dance memiliki spesifikasi berupa sebuah kartu yang di dalamnya memuat sebuah gambar tarian, diantaranya seperti tarian dari daerah provinsi di Indonesia tanpa ada keterangan nama tarian. Kartu ini bersifat tematik berdasarkan asal daerah provinsi yang sama, per tema terdapat $>$ dari 5 jenis tarian.

Media ini pernah diaplikasikan di kelas Seni Sabuk Janur yang bertempat di Padepokan Reyog Ponorogo, jalan Pramuka no. 19A Ponorogo, namun belum ideal karena bentuknya masih sederhana. Meskipun kondisi media ini masih sederhana, tetapi tidak mengurangi esensi dari pembelajaran yang dilakukan dan menuai hasil yang optimal.Dari hasil pengembangan tersebut diharapkan tumbuh kesadaran dan kebanggaan untuk mencintai sepenuh hati seni budaya yang mencerminkan nilai-nilai moral bangsa dan identitas bangsa di tengah-tengah masyarakat.

Sebuah penelitian lanjutan tentang proses pengembangan media card dance untuk pembelajaran seni taridilakukan pada mahasiswa prodi PGSD Universitas Hasyim Asy'ari Tebuireng Jombang, dan terbukti kualitas media pembelajaran yang dikembangkan sangat baik, danimplementasi media pembelajaran di kelas dapat dilakukan dengan baik.

Gambaran proses pengembangan media card dance untuk pembelajaran seni tari sebagai berikut: (1) card dance didesain sesuai dengan tarian-tarian yang akan dipelajari; (1) pemberian pengetahuan dasar tentang sejarah, bentuk, dan ciri khas dasar dari berbagai tarian yang dipelajari; (2) mengelompokkan peserta tari, misalkan dibagai kelompok $a$ dan $b$ disesuaikan jumlah peserta kemudian membuat game atau permainan untuk kelompok tari. (3) kemudian pembelajaran seni tari dapat dilakukan dengan berbagai metode atau cara diantarany yaitu card dance ditunjukkan kemudian peserta didik menebak jenis tarian dan kemudian mempraktekkannya, guru tari mempraktekkan tarian kemudian peserta didik menebak dengan Card Dance. 
Penggunaan media sangat penting kehadirannya dalam pembelajaran, karena dapat membantu guru dalam menyampaikan materi yang mungkin tidak dapat disampaikan hanya dengan lisan.Sehingga, dapat meningkatkan pemahaman siswa.Penggunaan media pembelajaran haruslah disesuaikan dengan efektivitas, efisiensi media, kualitas media, sesuai dengan minat, kebutuhan dan kondisi siswa, dan kemampuan guru dalam mengoperasikan (Esti dan Sukanti, 2012).

Media pembelajaran terbagi dalam beberapa macam jenis, namun kesemuanya memiliki manfaat yang sama dan memiliki peranan yang sama. Menurut Hujair AH Sanaky (2015) macam-macam media pembelajaran yaitu media grafis, visual, audio, audio dan visual, tiga dimensi, proyeksi.

Dari macam- macam media pembelajaran tersebut diatas, semuanya memiliki manfaat yang sama, namun terdapat perbedaan dalam penggunaannya dan terdapat perbedaan dalam pencapaian pengalaman belajar yang ditempuh.
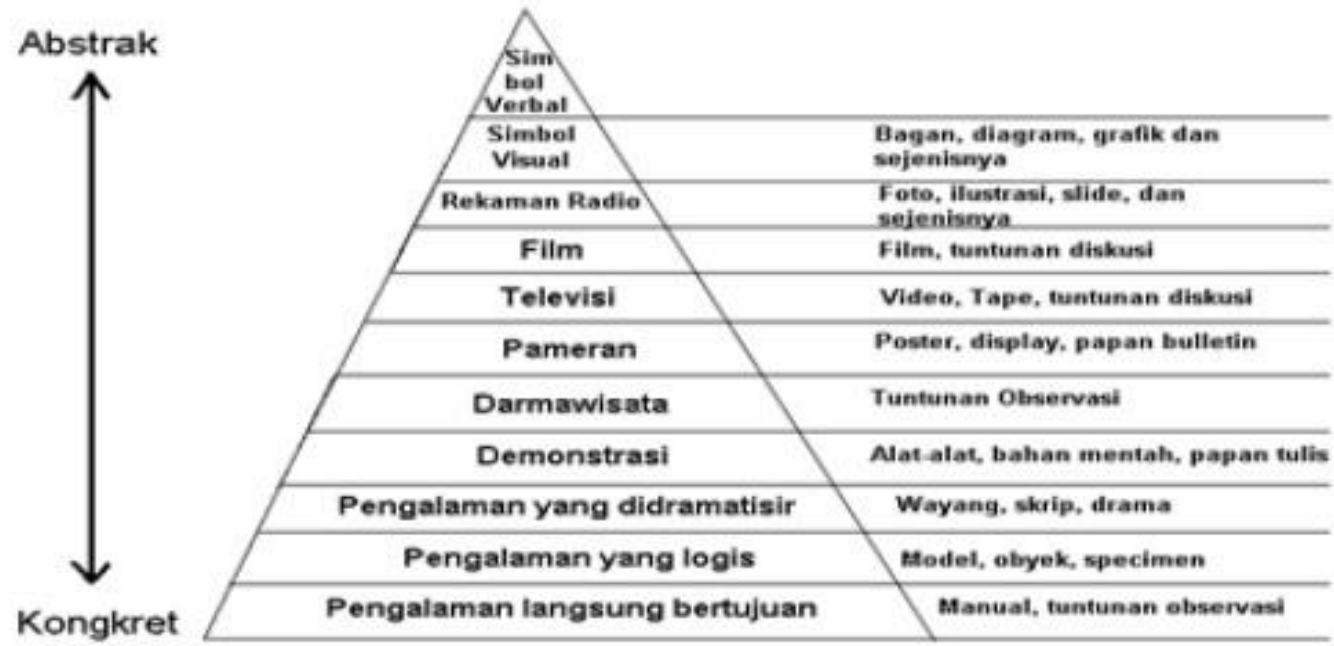

(Hujair AH Sanaky, 2013: 47)

Gambar 1 Kerucut pengalaman belajar menurut Edgar Dale

Kertas adalah bahan yang tipis dan rata, yang dihasilkan dengan kompresi serat yang berasal dari pulp (Paskawati dkk, 2010). Di pasaran, terdapat beberapa macam kertas yang digunakan oleh masyarakat, antara lain, alumunium foil, kertas cellophane, karton, duplex, kertas majalah, tas kertas, kertas serbet, kertas pastel, kertas merang, kertas tissue, wallpapers, watercolor paper, kertas minyak, kertas metalik, dan kertas daur ulang(kertas seni). 
Kualitas media card dance dapat disesuaikan dengan kebutuhan dan sesuai tingkatan lembaga Pendidikan sebagai berikut: (a) tingkat Sekolah Dasar (SD sampai dengan SMP) sebaiknya menggunakan kertas yang tidak mudah rusak dan tidak berbahaya bagi kesehatan pelajar, seperti kertas karton, kertas HVS, (b) tingkat Sekolah Menengah sampai Tingkat Perguruan Tinggi sebaiknya lebih mengedepankan kreatifitas siswa, sehingga kertas atau media yang digunakan tidak terpaku pada gambar tari 2 dimensi, namun dari media tersebut justru bisa dibentuk sedemikian rupa sesuai kreatifitas siswa juga.

Kualitas media pembelajaran menjadi faktor yang sangat berpengaruh dalam peningkatan motivasi belajar siswa.Hal ini dikarenakan kualitas media pembelajaran, mampu memperjelas penyampaian materi pelajaran.Menurut Heinich dalam Arsyad (2013:4) Apabila media itu membawa pesan-pesan atau informasi yang bertujuan instruksional atau mengandung maksud-maksud pengajaran maka media itu disebut media pembelajaran”.

Untuk mendapatkan kualitas media pembelajaran yang baik agar dapat memberikan pengaruh yang signifikan dalam proses belajar mengajar, maka diperlukan pemilihan dan perencanaan penggunaan media pembelajaran yang baik dan tepat. Pemilihan media pembelajaranyang tepat ini menjadikan media pembelajaran efektif digunakan (Arsyad, 2013: 74).

Beberapa kualitas media card dance untuk pembelajaran seni tari pada lembaga Pendidikan dapat dilihat dari keunggulan berikut: (a) meningkatkan motivasi belajar peserta didik, (b) meningkatkan hasil belajar peserta didik, (c) mudah dibawa kemana-mana karena ukurannya relatif kecil, (d) praktis dalam menggunakannya, sehingga dapat digunakan kapan pun siswa ingin belajar, (e) mudah diingat karena kartu ini memiliki gambar dan tulisan yang sangat menarik perhatian, (f) media kartu bergambar juga sangat menyenangkan karena dapat digunakan dalam bentuk permainan (Dina Indriana, 2011: 69)

Meskipun memiliki berbagai kelebihan media kartu bergambar juga memiliki beberapa kekurangan. Arief S. Sadiman (2011: 31), mengemukakan beberapa kekurangan dari media gambar, sebagai berikut: (a) gambar / foto hanya menekankan pada indra mata, (b) gambar benda yang terlalu kompleks kurang 
efektif untuk kegiatan pembelajaran, (c) ukurannya sangat terbatas untuk kelompok besar.

Pengumpulan dan penilaian kualitas produk media pembelajaran mengacu pada kriteria kualitas menurut Nieven (dalam Khabibah, 2006:43) suatu material dikatakan baik jika memenuhi aspek-aspek kualitas, antara lain: (a) validitas, (b) kepraktisan, dan (c) keefektifan. Berdasarkan kriteria menurut kualitas Nieven tersebut, maka untuk mengetahui tingkat validitas, kepraktisan dan keefektifan , pengumpulan data mengacu pada ukuran kualitas media. Ukuran kualitas sebagai berikut: Berkualitas antara lain Bentuk, berat, dan besar media sesuai dengan ukuran fisik mahasiswa (bisa dibawa dan bisa digunakan dengan mudah), Bahan media (kertas, tinta/cat/pewarna) ramah lingkungan dan tidak membahayakan, Warna media bervariasi dan tidak mencolok, Tampilan media media menarik dan bentuk gambar jelas serta sesuai dengan referensi dan bentuk aslinya.Tidak berkualitas antara lainBentuk, berat, dan besar media tidak sesuai dengan ukuran fisik mahasiswa (tidak terlalu besar, dan berat). Sehingga menyulitkan mahasiswa untuk menggunakan, Bahan media (kertas, tinta/cat/pewarna) tidak ramah lingkungan dan membahayakan, Warna media mencolok sehingga bisa merusak mata, Desain bentuk media bisa melukai/ mencederai.

Kualitas media pembelajaran card dance yang dikembangkan (dihasilkan) dimintakan penilaian oleh dua ahli yang berbeda yaitu satu orang ahli materi di dalam pembelajaran seni tari/budaya dan satu orang ahli bidang desain grafis/ahli desain visual. Berikut tabel 1 yaitu nama-nama validator dan bidangnya.

Tabel 1 Validator Kualitas Media

\begin{tabular}{ccll} 
No & \multicolumn{1}{c}{ Nama } & \multicolumn{1}{c}{ Ahli } & Validasi \\
\hline 1. & Dr. Setyo Yanuartuti, M.Si & $\begin{array}{l}\text { Pendidikan seni budaya } \\
\text { UNESA }\end{array}$ & Materi seni tari \\
\hline 2. & Dr. Dody Doerjanto, M.Sn & $\begin{array}{l}\text { Pendidikan seni rupa, } \\
\text { desain dan teknologi } \\
\end{array}$ & pembelajaran UNESA \\
& & Kartu bergambar tari \\
\hline
\end{tabular}

Validasi ahli ini dilakukan untuk mengukur tingat kevalidan media card dance pembelajaran seni tari secara teoretis menurut penilaian dan pendapat dari para ahli sebelum dilakukan uji coba pengguna. Hasil dari validasi ahli berupa 
penilaian, tanggapan, saran dan masukan untuk card dance (kartu bergambar tari) pembelajaranseni tari yang dikembangkan oleh peneliti. Berikut di paparkan pada tabel 2 yaitu hasil penilaian validasi ahli.

\section{Tabel 2 Hasil Penilaian Validasi Ahli}

\begin{tabular}{|c|c|c|c|c|}
\hline \multirow[t]{2}{*}{ No. } & \multirow[t]{2}{*}{ Subjek } & \multicolumn{2}{|c|}{ Skor } & \multirow{2}{*}{$\begin{array}{c}\text { Hasil Persentasi } \\
\text { Perolehan }(\%)\end{array}$} \\
\hline & & Perolehan & Maksimal & \\
\hline 1. & Validasi media card dance & 55 & 64 & $85 \%$ \\
\hline 2. & Validasi ahli materi & 54 & 84 & $64 \%$ \\
\hline & Total Persentasi & 109 & 148 & $149 \%$ \\
\hline & Rata-rata & $\mathbf{5 4 , 5}$ & 74 & $74,5 \%$ \\
\hline
\end{tabular}

Validator ahli selain memberikan penilaian card dance pembelajaran seni tari, juga memberikan saran dan masukan guna perbaikan/revisi. Dari saran dan masukan validasi ahli, data disimpulkan sebagaiberikut (1) format: ukuran dan setting dikembangkan lebih baik lagi; (2) kesesuaian tari dengan gambar; (3) kejelasan uraian dari mana asal tari; (4) editan gambar/warna diperjelas.

Hasil validasi dari dua ahli menunjukkan total skor perolehan sebesar 109 dari total skor maksimal 148. Setelah dianalisis dan dipersentasekan, nilai tersebut mendapatkan hasil sebesar 74,5\%. Berdasarkan kriteria kevalidan yang telah ditentukan, nilai tersebut masuk dalam kriteria layak digunakan dilapangan dengan sedikit revisi. Meskipun secara kuantitatif media card dancepembelajaran seni tari termasuk dalam kriteria valid, namun terdapat beberapa bagian yang harus direvisi berdasarkan saran dan masukan dari para ahli.

Dari hasil penghitungan di atas, media pembelajaran card danceyang dikembangkan masuk dalam kategori berkualitas, media yang dikembangkan baik dan bisa digunakan.

\section{KESIMPULAN DAN SARAN}

Kelebihan media card dance adalah Media ini praktis dan luwes saat digunakan dan bisa dibawa kemana-mana; membuat pembelajaran lebih menyenangkan, bermakna dan pengetahuan peserta didik lebih tahan lama; sebagai wujud pengenalan budaya untuk menumbuhkan cinta akan budaya pada 
masyarakat luas melalui pembelajaran seni tari; Card dance ini juga memiliki spesifikasi berupa sebuah kartu yang di dalamnya memuat sebuah gambar tarian dari daerah provinsi di Indonesia. Kartu ini bersifat tematik berdasarkan asal daerah provinsi yang sama, per tema terdapat $>$ dari 5 jenis tarian.

Berdasarkan hasil kualitas media card dance pembelajaran seni tari tersebut dapat disimpulkan bahwa media card dance memiliki kualitas yang baik dan berpredikat layak digunakan untuk menunjang pembelajaran. Selain itu beberapa saran untuk tindak lanjut bagi penelitian selanjutnya yaitu diharapkan inovasi media card dance dilaksanakan selain pada pembelajaran seni tari dan dapat menggunakan gambar tiga dimensi agar kualitas media semakin bagus.

\section{DAFTAR PUSTAKA}

A.M. Sardiman. 2011. Interaksi dan Motivasi Belajar Mengajar. Jakarta: Rajawali Press.

Abdul Rahman Sholeh. 2005. Pendidikan Agama dan Pengembangan untuk Bangsa. Jakarta: PT. Raja Grafindo.

Arif S. Sadiman, dkk. 2011. Media Pendidikan, Pengertian, Pengembangan, dan Pemanfaatannya. Jakarta: PT. Raja Grafindo Persada.

Dewi Risnaningtyas. 2016. "Pengaruh Penggunaan Media Kartu Bergambar Terhadap Hasil Belajar Ips Siswa Kelas V Sd Negeri Dayuharjo Sleman”. Journal UNY diakses dari http://eprints.uny.ac.id/30595/1/Dewi\%20Risnaningtyas.pdf.

Dina Indriana. 2011. Ragam Alat Bantu Media Pengajaran. Jogjakarta: Diva Pers.

Eko Budiyono. 2017. "Efektivitas Media Kartu Bergambar Melalui Model Stad TerhadapAktivitas Dan Hasil Belajar”. Journal Portal Garuda diakses dari http://download.portalgaruda.org.

Joko Muhammad. 2015. "Analisis kualitas media pembelajaran insektarium dan herbarium untuk mata pelajaran biologi sekolah menengah". Jurnal bioedukatika Vol.3 No.1 Mei 2015, Prog. Studi Pendidikan Biologi UAD. Journal diakses darijournal.uad.ac.id

Mahmud. 2011. Metode Penelitian Pendidikan. Bandung: Pustaka Setia. 
Ni Luh Sustiawati. 2018. "Pengembangan Desain Pembelajaran Seni Tari Di Sekolah Dasar Berbasis Localgenius KnowledgeBerpendekatan Integrated Learning" MUDRA Jurnal Seni Budaya Volume 33, Nomor 1, Februari 2018 p 128 - 143Marsudi (2012)

Sugiono. 2011. Metode Penelitian Kuantitatif Kualitatif dan $R \& D$. Bandung: Alfabeta.

Undang-Undang Nomor 20 Tahun 2003 tentang Sistem Pendidikan Nasional

Yusnizar Heniwaty. 2014. "Penggunaan multi media dalam penyusunan alur pembelajaran tari, mhs angkatan 2008/2009, prog. Studi senitari jur. Sendratasik)". Journal Media diakses dari https://media.neliti.com/media/publications/77146-ID-none 